\title{
PENGARUH IMPLEMENTASI MANAJEMEN KELAS TERHADAP HASIL BELAJAR PESERTA DIDIK DI SMK MUHAMMADIYAH WATANSOPPENG
}

\author{
${ }^{1}$ A. Sri Reski Amaliah, ${ }^{2}$ Muhammad Yahya, ${ }^{3}$ Ahmad Afiif \\ 1SMK Muhammadiyah Watansoppeng \\ 2Universitas Islam Negeri Alauddin Makassar \\ 3Universitas Islam Negeri Alauddin Makassar \\ E-mail: a.srireskiamaliah@gmail.com
}

\begin{abstract}
This research aimed to find the implementation and effect of classroom management on learning outcome of students. It is a field research with a quantitative approach, using descriptive quantitative statistic analysis as an analylis data technique. The results of the data found about the significance of classroom management on student learning outcomes at SMK Muhammadiyah Watansoppeng.
\end{abstract}

Keywords: Classroom Management, Learning Outcomes

\section{Abstrak}

Penelitian ini betujuan untuk mengetahui implementasi dan pengaruh manajemen kelas terhadap hasil belajar peserta didik. Penelitian ini adalah penelitian lapangan dengan pendekatan kuantitatif. Teknik pengumpulan data menggunakan kuesioner dan analisis dokumen. Teknik anaisis data menggunakan analisis statistik deskriptif kuantitatif. Hasil penelitian menemukan terdapat pengaruh signifikan manajemen kelas terhadap hasil belajar peserta didik di SMK Muhammadiyah Watansoppeng.

Kata Kunci: Manajemen Kelas, Hasil Belajar

\section{PENDAHULUAN}

Pendidikan pada hakekatnya merupakan proses pendewasaan manusia untuk menjadi pribadi yang bijaksana. Pendidikan dapat dikatakan sebagai penolong dalam menjalani kehidupan yang terus berkembang. Tanpa pendidikan manusia tidak akan maju dan takkan mampu untuk melakukan perubahan-perubahan sesuai dengan perkembangan zaman. Pendidikan merupakan wahana untuk meningkatkan dan mengembangkan kualitas sumber daya manusia, oleh karena itu pendidikan memiliki andil yang sangat besar dalam perkembangan suatu bangsa.

Menurut Undang Undang Republik Indonesia Nomor 20 tahun 2003 tentang Sistem Pendidikan Nasional, pendidikan adalah usaha sadar dan terencana untuk mewujudkan suasana belajar dan proses pembelajaran agar peserta didik secara aktif mengembangkan potensi dirinya untuk memiliki kekuatan spiritual keagamaan, pengendalian diri, kepribadian, kecerdasan, 


\section{2 | A. Sri Reski Amaliah, Muhammad Yahya, Ahmad Afiif}

akhlak mulia, serta keterampilan yang diperlukan dirinya, masyarakat, bangsa, dan negara.1

Tujuan pendidikan dapat tercapai sesuai dengan yang diamanatkan oleh Undang Undang Republik Indonesia Nomor 20 tahun 2003 tentang Sistem Pendidikan Nasional bahwa; Tujuan pendidikan nasional adalah untuk berkembangnya potensi peserta didik agar menjadi manusia yang beriman dan bertakwa kepada Tuhan Yang Maha Esa, berakhlak mulia, sehat berilmu, cakap, kreatif mandiri, dan menjadi warga Negara yang demokratis serta bertanggung jawab. 2

Peningkatan mutu pendidikan akan tercapai apabila proses belajar mengajar yang diselenggarakan di kelas benar-benar efektif dan berguna untuk mencapai kemampuan pengetahuan, sikap dan keterampilan yang diharapkan. Proses belajar mengajar pada dasarnya merupakan inti dari proses pendidikan secara keseluruhan, di antaranya guru merupakan salah satu faktor yang penting dalam menentukan berhasilnya proses belajar mengajar di dalam kelas. Oleh karena itu guru dituntut untuk meningkatkan peran dan kompetensinya.

Guru memiliki peranan sangat penting untuk meningkatkan hasil belajar peserta didik. Untuk itu menciptakan lingkungan belajar yang efektif dan mampu mengelola kelas harus dipahami oleh guru. Kelas merupakan lingkungan belajar serta merupakan suatu aspek dari lingkungan sekolah yang perlu diorganisir. Lingkungan ini perlu diatur dan diawasi agar kegiatan-kegiatan belajar terarah kepada tujuan-tujuan pendidikan. Lingkungan yang baik bersifat menantang dan merangsang peserta didik untuk belajar, memberikan rasa aman dan kepuasan dalam mencapai hasil belajar yang diharapkan. Untuk menciptakan dan mewujudkan suasana kelas yang efektif, seorang guru harus memahami dan mengetahui manajemen kelas.

Manajemen kelas adalah usaha yang diarahkan oleh guru untuk mewujudkan suasana belajar mengajar yang efektif dan menyenangkan serta dapat memotivasi peserta didik untuk belajar dengan baik sesuai dengan kemampuan. Menurut Alam S, manajemen kelas adalah rentetan kegiatan guru untuk menumbuhkan dan mempertahankan organisasi kelas yang efektif, yaitu meliputi : tujuan pengajaran, pengaturan waktu, pengaturan ruang dan peralatan, dan pengelompokan peserta didik dalam belajar. ${ }^{3}$

Guru yang kompeten akan lebih mampu menciptakan lingkungan belajar yang efektif dan akan lebih mampu mengelola kelasnya sehingga hasil

\footnotetext{
${ }^{1}$ Hasbullah, Dasar-dasar Ilmu Pendidikan, (Jakarta: Rajawali Pers, 2012), h. 4.

${ }^{2}$ Hasbullah, Dasar-dasar Ilmu Pendidikan, h. 307

${ }^{3}$ Tim Dosen Administrasi Pendidikan Univesitas Pendidikan Indonesia, Manajemen Pendidikan (Bandung: Alfabeta, 2011) h. 107
} 
belajar peserta didik berada pada tingkat yang optimal. Hasil belajar adalah suatu yang dicapai atau diperoleh peserta didik berkat adanya usaha atau pikiran yang mana hal tersebut dinyatakan dalam bentuk penguasaan, pengetahuan dan kecakapan dasar yang terdapat dalam bebagai aspek kehidupan sehingga nampak perubahan tingkah laku para individu. Menurut Sukmadinata, hasil belajar atau achievement merupakan realisasi atau pemekaran dari kecakapan-kecakapan potensial atau kapasitas yang dimiliki seseorang.4

Berdasarkan hasil wawancara dari salah satu guru bidang studi bahasa Indonesia SMK Muhammadiyah Watansoppeng, Rosbaena, S.Pd. mengemukakan bahwa guru pada umumnya menyampaikan pembelajaran dengan metode ceramah, guru juga kurang memaksimalkan perabotan yang ada di ruang kelas dan hasil belajar di SMK Muhammadiyah Watansoppeng masih bermasalah. Hal tersebut ditandai dengan nilai ulangan semester peserta didik yang masih tergolong rendah dan masih ada beberapa peserta didik dibawah kriteria ketuntasan minimal (KKM) yang telah ditetapkan.

Berdasarkan penjelasan di atas maka peneliti akan mengkaji secara ilmiah tentang Pengaruh Implementasi Manajemen Kelas terhadap Hasil Belajar Peserta didik di SMK Muhammadiyah Watansoppeng.

\section{METODE}

Penelitian ini ialah penelitian lapangan dengan menggunakan pendekatan kuantitatif. Dari 124 orang peserta didik yang menjadi populasi, diambil 31 orang atau $25 \%$ dari jumlah populasi untuk dijadikan sebagai sampel dengan menggunakan teknik "random sampling". Angket yang disusun dalam bentuk model Skala Likert terhadap variabel implementasi manajemen kelas. Analisis dokumen atau teknik dokumentasi ditujukan pada pengumpulan data variabel hasil belajar. Data dianalisis menggunakan aplikasi SPSS versi 20 (for windows).

\section{IMPLEMENTASI MANAJEMEN KELAS}

Implementasi manajemen kelas di SMK Muhammadiyah Watansoppeng berada pada kondisi sedang. Hal tersebut didasarkan pada data penelitian yang diperoleh dari angket yang telah disebar. Berikut ini, presentase skor implementasi manajemen kelas di SMK Muhammadiyah Watansoppeng:

\footnotetext{
${ }^{4}$ Euis Karwati dan Donni Juni Priansa, Manajemen Kelas (Bandung: Alfabeta, 2014), h. 216.
} 
Tabel 1

Kategori Skor Implementasi Manajemen Kelas di SMK Muhammadiyah Watansoppeng

\begin{tabular}{|c|c|c|c|c|}
\hline Batas Kategori & Interval & Frekuensi & Kategori & Persentase \\
\hline$X<(\mu-1,0 \sigma)$ & $X<63$ & 3 & Rendah & $9,67 \%$ \\
\hline$(\mu-1,0 \sigma) \leq X<(\mu+1,0 \sigma)$ & $63 \leq X<75$ & 23 & Sedang & $74,14 \%$ \\
\hline$X \geq(\mu+1,0 \sigma)$ & $X \geq 75$ & 5 & Tinggi & $16,12 \%$ \\
\hline Jumlah & 31 & & $100 \%$ \\
\hline
\end{tabular}

\section{HASIL BELAJAR PESERTA DIDIK}

Untuk hasil belajar peserta didik di SMK Muhammadiyah Watansoppeng peneliti menggunakan metode dokumentasi yakni dengan melihat nilai rata-rata ulangan semester dari rekapitulasi wali kelas dari 31 peserta didik, dengan menggunakan simple random sampling. Presentase skor hasil belajar dapat dilihat pada table di bawah ini:

Tabel 2

Kategori Skor Hasil Belajar Peserta Didik SMK Muhammadiyah Watansoppeng

\begin{tabular}{|c|c|c|c|c|}
\hline Batas Kategori & Interval & Frekuensi & Kategori & Persentase \\
\hline $\mathrm{X}<(\mu-1,0 \sigma)$ & $\mathrm{X}<79$ & 6 & Rendah & $19,35 \%$ \\
\hline$(\mu-1,0 \sigma) \leq \mathrm{X}<(\mu+1,0 \sigma)$ & $79 \leq \mathrm{X}<87$ & 22 & Sedang & $70,96 \%$ \\
\hline $\mathrm{X} \geq(\mu+1,0 \sigma)$ & $\mathrm{X} \geq 87$ & 3 & Tinggi & $9,67 \%$ \\
\hline \multicolumn{2}{|c|}{ Jumlah } & 31 & & $100 \%$ \\
\hline
\end{tabular}

Berdasarkan tabel 2, dengan memperhatikan 31 peserta didik sebagai sampel, 6 atau 19,35\% peserta didik yang barada dalam kategori rendah, 22 atau 70,96\% peserta didik yang barada dalam kategori sedang, 3 atau 9,67\% peserta didik yang barada dalam kategori tinggi. Hal tersebut menggambarkan bahwa, hasil belajar peserta didik di SMK Muhammadiyah Watansoppeng berada dalam kategori sedang.

\section{PENGARUH IMPLEMENTASI MANAJEMEN KELAS TERHADAP HASIL BELAJAR PESERTA DIDIK}

Berdasarkan hasil uji $\mathrm{t}$ dalam penelitian ini, diperoleh $t_{\text {hitung }}=$ 30,02 dengan taraf signifikan 5\% uji dua pihak, $\mathrm{db}=\mathrm{n}-2=29$ diperoleh $t_{0,025(29)}=2,045$, jadi $t_{\text {hitung }}=30,02 \geq t_{0,025(29)}=2,045$. Hasil 
tersebut menggambarkan bahwa terdapat pengaruh yang positif sebesar 30,02 antara implementasi manajemen kelas dengan hasil belajar peserta didik.

Implementasi manajemen kelas yang mempengaruhi hasil belajar dalam penelitian ini dilihat dari kemampuan guru. Menurut Novan Ardi Wiyani ada tiga kegiatan inti yang harus dikuasai oleh guru dalam implementasi manajemen kelas, yaitu; menciptakan iklim belajar, mengatur ruang belajar, dan mengelolah interaksi belajar mengajar. ${ }^{5}$

Menciptakan iklim belajar yang tepat bertujuan untuk mewujudkan suasana kelas yang kondusif dan menyenangkan agar dapat memotivasi peserta didik untuk dapat belajar dengan baik. Iklim belajar yang aman dan tertib akan membuat proses belajar mengajar berlangsung dengan nyaman. Untuk menciptakan iklim belajar yang tepat, seorang guru sabagai manajer diantaranya harus mampu memotivasi peserta didik, mampu menghidupkan suasan belajar, mampu menggunakan alat dan media pembelajaran yang bervariasi, serta mampu menggunakan startegi belajar. Guru yang mampu menguasai hal tersebut dapat meningkatkan motivasi belajar peserta didik untuk belajar lebih baik dan memperoleh hasil bejar yang baik pula. Semakin baik kemampuan guru dalam memotivasi siswa maka kemauan siswa untuk belajar dengan baik akan semakin tinggi dan hal tersebut akan mempengaruhi hasil belajarnya, begitu pula dalam menghidupkan suasana belajar, menggunakan alat dan media pembelajaran yang bervariasi, serta menggunakan strategi.

Selain mencipatkan iklim belajar yang tepat, seorang guru juga harus bisa mengatur ruang belajar. Ruang belajar dalam hal ini adalah ruang kelas tempat dimana peserta didik menerima pelajaran dari guru. Ruang kelas yang tertata dengan rapi akan memunculkan semangat serta keinginan untuk belajar bagi peserta didik. Hal-hal yang harus diperhatikan oleh guru dalam mengatur ruang belajar yaitu, tempat duduk peserta didik, media pendidikan, pengaturan tanaman hias, serta pemberian aroma terapi.

Pengaturan tempat duduk peserta didik harus bagus, tidak terlalu tinggi, dan tidak terlalu rendah, tidak terlalu besar dan tidak terlalu kecil, tidak terlalu berat dan sesuai dengan postur tubuh peserta didik, selain itu pengaturan posisi tempat duduk peserta didik di kelas juga sangat penting. ${ }^{6}$ Pengaturan tempat duduk peserta didik, pengaturan media pendidikan, tanaman hias, dan pemberian aroma terapi dimaksudkan agar peserta didik

\footnotetext{
${ }^{5}$ Novan Ardi Wiyani, Manajemen Kelas: Teori dan Aplikasi untuk Menciptakan Kelas yang Kondusif, h. 65.

${ }^{6}$ Novan Ardi Wiyani, Manajemen Kelas: Teori dan Aplikasi untuk Menciptakan Kelas yang Kondusif, h. 106.
} 


\section{6 | A. Sri Reski Amaliah, Muhammad Yahya, Ahmad Afiif}

merasa nyaman dan bersemangat pada saat menerima pelajaran, dengan demikian pembelajaran akan mudah dipahami oleh peserta didik dan akan berpengaruh pada hasil belajarnya.

Hal terakhir yang harus dikuasai guru, yaitu mengelolah interaksi belajar mengajar. Untuk menciptakan interaksi belajar mengajar yang efektif setidaknya guru harus menguasai dan mempraktikkan berbagai keterampilan dasar mengajar. Menurut Udin Syaefuddin Saud, keterampilan guru dalam proses belajar mengajar antara lain; keterampilan membuka dan menutup pelajaran, keterampilan menjelaskan, keterampilan bertanya, keterampilan memberi penguatan, keterampilan mengguanakan media pembelajaran, keterampilan membimbing diskusi kelompok kecil, keterampilan mengelola kelas, keterampilan mengadakan variasi serta keterampilan mengajar perorangan dam kelompok kecil. ${ }^{7}$ Guru diharapkan menguasai hal tersebut dimaksudkan agar peserta didik lebih aktif dalam proses pembelajaran, bukan hanya sekedar menerima pelajaran tetapi juga mampu memberikan umpan balik dan mencapai hasil belajar yang maksimal.

Ketiga kegiatan inti dalam implementasi manajemen kelas tersebut apabila diterampkan dan dikuasai oleh guru maka akan mempengaruhi hasil belajar peserta didik. Semakin baik implementasi manajemen kelas yang dilakukan oleh guru, maka semakin tinggi pula hasil belajar peserta didik, begitupun sebaliknya, semakin buruk implementasi manajemen kelas yang dilakukan oleh guru, maka semakin rendah pula hasil belajar peserta didik.

\section{PENUTUP}

Berdasarkan hasil analisis data maka dapat disimpulkan bahwa implementasi manajemen kelas di SMK Muhammadiyah Watansoppeng berada dalam kategori sedang, hal tersebut diperoleh dari hasil analisis data 31 peserta didik dengan rincian 3 atau 9,67\% peserta didik berada pada kategori rendah, 23 atau 74,14\% peserta didik berada pada kategori sedang, 5 atau 16,12\% berada pada kategori sedang. Kemudian, hasil belajar peserta didik di SMK Muhammadiyah Watansoppeng berada dalam kategori sedang, hal tersebut dari hasil analisis data 31 peserta didik dengan rincian 6 atau 19,35\% peserta didik berada pada kategori rendah, 22 atau 70,96\% peserta didi berada dalam kategori sedang, 3 atau 9,67\% peserta didik berada dalam kategori sedang. Selanjutnya, berdasarkan uji hipotesis dimana $t_{\text {hitung }} \geq t_{\text {tabel }}=$ $30,02 \geq 2,045$, hal tersebut menunjukkan bahwa terdapat pengaruh yang signifikan implementasi manajemen kelas terhadap hasil belajar peserta didik di SMK Muhammadiyah Watansoppeng.

\footnotetext{
${ }^{7}$ Udin Syaefuddin Saud, Pengembangan Profesi Guru (Bandung: Alfabeta, 2011), h. 55.
} 
Dalam proses pembelajaran, pendidik dalam hal ini guru sebaiknya memahami implementasi manajemen kelas, terutama ketiga aspeknya yaitu menciptakan kondisi kelas yang tepat, mengatur ruang belajar, dan mengelolah interaksi belajar mengajar yang masih tergolong sedang. Guru hendaknya lebih meningkatkan cara mengajar, penggunaan alat/media dan strategi yang bervariasi, dan penguasaan keterampilan mengajar.

Dalam menunjang aktivitas guru dalam mengimplementasikan manajemen kelas, Kepala Sekolah sebaiknya memberikan bekal kepada guru berupa pengetahuan dan keterampilan serta pengalaman tentang implementasi manajemen kelas yang baik melalui pelatihan dan rutin dalam melakukan pengawasan serta evaluasi terhadap proses dan hasil manajemen kelas yang telah diimplementasikan oleh guru.

Dalam implementasi manajemen kelas, bagian sarana prasarana sebaiknya meningkatkan pengadaan fasilitas sarana prasarana sekolah yang menunjang pembelajaran, seperti meja dan kursi yang lebih sesuai dengan postur tubuh peserta didik sehingga nyaman pada saat digunakan, alat/media yang diperlukan guru dalam proses belajar mengajar, dan ruang belajar yang senantiasa bersih.

Dalam menunjang aktivitas guru dalam mengimplementasikan manajemen kelas, Pemerintah memiliki andil yang sangat besar. Dalam hal ini pemerintah lebih memperhatikan kempampuan guru terutama kemampuan mengimplementasikan manajemen kelas. Mengadakan pelatihan dan bekerja sama dengan sekolah-sekolah, terutama sekolah yang guru - gurunya masih kurang dalam pengimplementasian manajemen kelas dan sebaiknya secara berkesinambungan.

\section{DAFTAR PUSTAKA}

Hasbullah. Dasar-dasar Ilmu Pendidikan. Jakarta: Rajawali Pers, 2012.

Karwati, Euis dan Donni Juni Priansa. Manajemen Kelas. Bandung : Alfabeta, 2014.

Saud, Udin Syaefuddin. Pengembangan Profesi Guru, Bandung: Alfabeta, 2011.

Tim Dosen Administrasi Pendidikan Univesitas Pendidikan Indonesia. Manajemen Pendidika., Bandung: Alfabeta, 2011.

Wiyani, Novan Ardy. Manajemen Kelas: Teori dan Aplikasi untuk Menciptakan Kelas yang kondusif. Yogyakarta: Ar-Ruzz Media, 2013. 
8 | A. Sri Reski Amaliah, Muhammad Yahya, Ahmad Afiif

HALAMAN INI SENGAJA DIKOSONGKAN 